Omni-Akuatika, 13 (2): 6-15, 2017
ISSN: 1858-3873 print / 2476-9347 online
Research Article

\title{
Specific Immune Response Kinetics and Mortality Patterns of Tilapia Oreochromis niloticus on Post-Cocktail Vaccination Period against the Infection of Aeromonas hydrophila and Streptococcus agalactiae
}

\author{
Sukenda Sukenda ${ }^{1 *}$, Tuti Sumiati $^{2}$, Sri Nuryati ${ }^{1)}$, Angela Mariana Lusiastuti ${ }^{2)}$, Dendi \\ Hidayatullah $^{\text {i) }}$ \\ ${ }^{1)}$ Departemen Budidaya Perairan, Fakultas Perikanan dan IImu Kelautan, Institut Pertanian Bogor \\ Jl. Lingkar Akademik Kampus IPB Darmaga Bogor, Indonesia \\ 2) Instalasi Penelitian dan Pengembangan Pengendalian Penyakit lkan \\ J. Perikanan No. 13, Depok, Indonesia \\ *Corresponding author: sukenda67@gmail.com
}

Received 12 January 2017; Accepted 11 June 2017; Available online 27 November 2017

\begin{abstract}
Fish vaccination aims to induce a specific immune response indicated by an increase of antibodies in vaccinated fish. However, in accordance with time, the presence of antibodies will continue to decline. The purpose of this study was to determine the kinetics of specific immune response and trend mortality against Aeromonas hydrophila and Streptococcus agalactiae on tilapia following vaccination with a cocktail vaccine. Fish was vaccinated through immersion for 30 minutes in a solution of diluted vaccine. Challenge test was performed for three periods, on day 22,50 , and 78 post-vaccination, fish were challenged with single infection of $A$. hydrophila $10^{8} \mathrm{cfu}^{-\mathrm{mL}^{-1}}$ and $S$. agalactiae $10^{4} \mathrm{cfu}$. $\mathrm{mL}^{-1}$ and co-infection of both bacteria by intraperitoneal. During rearing, the blood fish were taken for determining of serum antibodies, which was measured by ELISA. The results showed that the concentration of specific antibodies vaccinated fish were significantly higher than the control. The basal antibody levels of $A$. hydrophila before vaccination were higher than $S$. agalactiae with OD of 0.104 and 0.069 respectively. The maximum antibody response was reached within 70 days of the $A$. hydrophila $\mathrm{OD}=0.264$ and 56 days against $S$. agalactiae $\mathrm{OD}=0.188$. The mortality rate in the control group was significantly higher than vaccinated on all types and each challenge test period. The trend of mortality due to a single infection of $A$. hydrophila and coinfections occur more quickly than by $S$. agalactiae. Lowest mortality occurred in the vaccinated group at 50 days tested challenge.
\end{abstract}

Keywords: kinetics antibody, Aeromnas hydrophila, Streptococcus agalactiae, Oreochromis niloticus

\section{Introduction}

Immune responses existed in a fish consist of non-specific immune response (innate) and specific immune response (adaptive) (Iwama and Nakanishi, 1996). A specific immune response induction is indicated by an increased in the antibody production in the vaccinated fish. Vaccination aims to induce long-term immunity by stimulating the specific immune response component (antibody memory) (Ellis, 1988). Vaccination can be performed by several application methods, including injection, immersion, spraying, and oral administration. Immersion method is preferably used in the aquaculture industry because it is more applicable than injection technique and produces a better protection in providing immunity than oral technique through feeding (Ellis, 1989). 
Studies about vaccination in tilapia to protect it from pathogenic bacterial infection have been widely studied. There are several studies on vaccination subjected to tilapia against Streptococcus sp. and Aeromonas hydrophila (Pasnik et al., 2006; Prasad and Areechon, 2010; Hardi et al., 2010; Sugiani and Komarudin 2011; Taukhid and Purwaningsih, 2011; Sugiani et al., 2012). The vaccination goals are the formation of specific antibodies and a positive result indicated by a high survival that will be achieved by paying attention to several terms, ie the vaccine must be immunogenic, produces a long protective time and is safe too (Sommerset et al., 2005).

Along with the rearing time, the specific immune response that can protect a fish from a pathogen infection will continue to decline. Romalde et al. (1999) studied on toxoid from Streptococcus sp. and found that the protection provided by this vaccine decreased along with time. Therefore, this study aimed to analyze specific immune response kinetics and mortality patterns in tilapia vaccinated with the cocktail vaccine, then tested against single infections of $A$. hydrophila and $S$. agalactiae, and also co-infection of both pathogenic bacteria.

\section{Methods}

\section{Fish}

Tilapias with an average weight of 16.5 $\mathrm{g}$ were obtained from Research Installation of Freshwater Cultured Fish Germplasm Cijeruk. Based on verification results through microbiological test and observation during the acclimatization period, there was no symptom of characteristics that would appear when the fish is infected by motile aeromonad septicemia MAS and streptococcosis or the fish condition had been stable.

\section{Vaccination}

The cocktail vaccine tested in this study was a mixture of inactivated $A$. hydrophila whole cell monovalent vaccine and inactivated $S$. agalactiae whole cell monovalent vaccine with a formulation of $25 \%$ A hydrophila and $75 \%$ S. agalactiae, at a concentration of $10^{11}$ cfu. $\mathrm{mL}^{-1}$ (Sumiati et al., 2012). Vaccination was performed by immersion technique. The vaccine was diluted first with a dose of $1 \mathrm{~mL}$ vaccine into $10 \mathrm{~L}$ clean water. In the vaccination group, the fish were immersed in a diluted vaccine solution for 30 minutes and that solution was aerated at the same time. The control fish were immersed in water without the vaccine. After vaccination, the fish were reared for 4 months in a pond with a volume of $10 \mathrm{~m}^{3}$ at a density of 20 individuals. $\mathrm{m}^{-3}$.

\section{Challenge test}

The antigen sources were $A$. hydrophila AHL0905-2 isolate inoculated on Tripticase Soy Agar (TSA) medium and $S$. agalactiae N14G isolate inoculated on Brain Heart Infusion Agar (BHIA) medium. The challenge tests were performed on three experimental groups, ie group one on day 22 after vaccination, group two on day 50 after vaccination, and group three on day 78 after vaccination. The challenge tests were performed with single bacterial infections of $A$. hydrophila $10^{7} \mathrm{cfu} . \mathrm{mL}^{-1}$ and $S$. agalactiae $10^{4}$ cfu. $\mathrm{mL}^{-1}$, and the co-infection of both pathogenic bacteria with a composition ratio of 1:1. The fish were injected via intraperitoneal route at a dose of $0.1 \mathrm{~mL}$ and were then reared for 14 days after the challenge test.

\section{Preparation of blood sample}

Serum samples were collected from 4 fish in each group (vaccination and control). Blood samplings were performed before vaccination and every two weeks after vaccination during the rearing period. Blood was taken without using anti-coagulant, then performed centrifugation and the obtained serum was stored in a freezer at a temperature of $-20^{\circ} \mathrm{C}$ prior to use for the next test.

\section{Antibody level}

Evaluation of specific immune response kinetics (antibody levels) of the vaccinated tilapia was performed through indirectenzymelinked immunosorbent assay (ELISA) method adopting a method described by Pasnik et al. (2005) and Sugiani et al. (2014). Antigens used to coat microtiter plate wells were the sonicated $A$. hydrophila or S. agalactiae whole 
cells with each concentration of $10 \mu \mathrm{g} . \mathrm{mL}^{-1}$, using 96 microtiter plate wells. Well was coated with $50 \mu \mathrm{L} A$. hydrophila or $S$. agalactiae antigen diluted in $50 \mu \mathrm{L}$ carbonicbicarbonate buffer $0.1 \mathrm{M}(\mathrm{pH} 9.6)$ with three replications, incubated overnight at a temperature of $4^{\circ} \mathrm{C}$ and rinsed three times with $0.01 \mathrm{M}$ phosphate buffer saline containing $0.05 \%$ Tween-20 (PBS-T). It was then covered with $3 \%$ bovine serum albumin(BSA), re-rinsed with PBS-T. Serum from each experimental group at a volume of $100 \mu \mathrm{L}$ was diluted at a ratio of 1:50 and was transferred to the microtiter plate well, incubated at a temperature of $25^{\circ} \mathrm{C}$ for an hour and re-rinsed. Specific antibody immunoglobulin rabbit antitilapia at a volume of $100 \mu \mathrm{L}(1: 200)$ was added into the microtiter plate, incubated for an hour at a temperature of $25{ }^{\circ} \mathrm{C}$, then rerinsed. Peroxidase conjugated goat anti rabbit IgG was diluted at a ratio of $1: 5000$, then added at a volume of $100 \mu \mathrm{L}$ into each well, incubated at a temperature of $25^{\circ} \mathrm{C}$ for an hour and re-rinsed with PBS-T. Onestep ultra TMB-ELISA $100 \mu \mathrm{l}$ was then added, incubated for 20 minutes at a temperature of $25^{\circ} \mathrm{C}$ and the reaction stopped by adding $1 \mathrm{M} \mathrm{H}_{2} \mathrm{SO}_{4} 100$ $\mu \mathrm{L}$. The microtiter plate was incubated at a temperature of $25^{\circ} \mathrm{C}$ for 5 minutes in a dark space and optical density (OD) was recorded at an absorbance of $450 \mathrm{~nm}$ in ELISAreader.

\section{Statistical analysis}

Data of antibody levels in the form of optical density (OD) values from the serum of vaccinated tilapia and control groups and mortality patterns were analyzed through descriptive statistic and were presented in charts.

\section{Results and Discussion}

The specific immune responses of tilapia from the vaccinated group and the control group were measured using ELISA, subjected to $A$. hydrophila and $S$. agalactiae antigens. The presence of specific antibodies was indicated by an increased in the antibody production in the vaccinated fish. Antibody production kinetics in the vaccinated fish group and the control subjected to $A$. hydrophila and $S$. agalactiae antigens are presented in Figure 1.

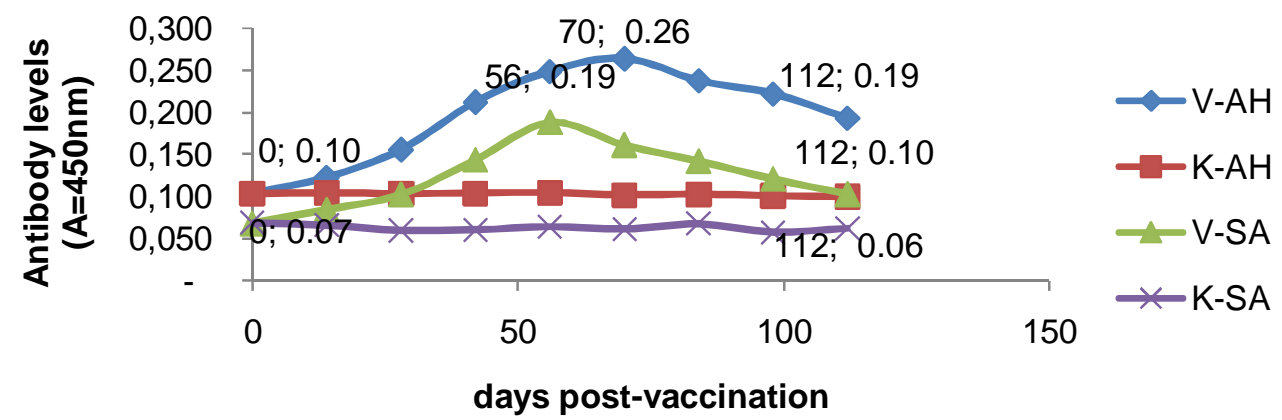

Figure 1.Specific antibodies kinetics of tilapia on post-vaccination period against $A$. hydrophila.and $S$. agalactiae antigens. $\mathrm{V}-\mathrm{AH}=$ the antibody of the vaccinated tilapia with coating $A$. hydrophila; $\mathrm{K}-\mathrm{AH}=\mathrm{the}$ antibody of the control fish with coating $A$. hydrophila; V-SA = the antibody of the vaccinated tilapia with coating $S$. agalactiae; K-SA = the antibody of the control fish with coating $S$. agalactiae. 
The basal antibody levels of tilapia against A.hydrophila were higher compared to $S$. agalactiae, with OD values were 0.104 and 0.069 , respectively. The antibody titer of the vaccinated fish serum was higher than that on control. The antibody concentration of the fish on postvaccination in the vaccinated group continued to increase, against both $A$. hydrophila and $S$. agalactiae. The maximum immune responses were reached on day 56 for $S$. agalactiaewith an OD value of 0.188 and day 70 against A.hydrophila with an OD value of 0.264 (Figure 1). This condition occurred allegedly because the characteristics of the two antigens were different, A. hydrophila is Gram negative bacteria group having complex structures compared to $S$. agalactiae as Gram positive bacteria group having a simpler structure. Antigenic determinants (epitopes) owned by A. hydrophila are more complex consisting of lipopolysaccharide (LPS), outer membrane protein(OMP), $\alpha$ and $\beta$ hemolysin, aerolysin, enterotoxin ACT, ALT and AST, protease, and RNase. Amonabactin, enterotoxin, and cytoxine are other virulence factors in Aeromonas species (Angka et al., 1995; Perez et al., 2002; Alavandi and Ananthan, 2003; Poobalane, 2007). Those substances are virulence factors and several virulence factors are immunogenic.

Based on the cumulative mortality rate of the experimental fish after the challenge test, the mortality patterns of the fish in each challenge test period with single bacterial infections of $A$. hydrophila and $S$. agalactiae, and co-infection of both bacteria could be observed. The mortality patterns of tilapia in the vaccinated group after the challenge test are presented in Figure 2.
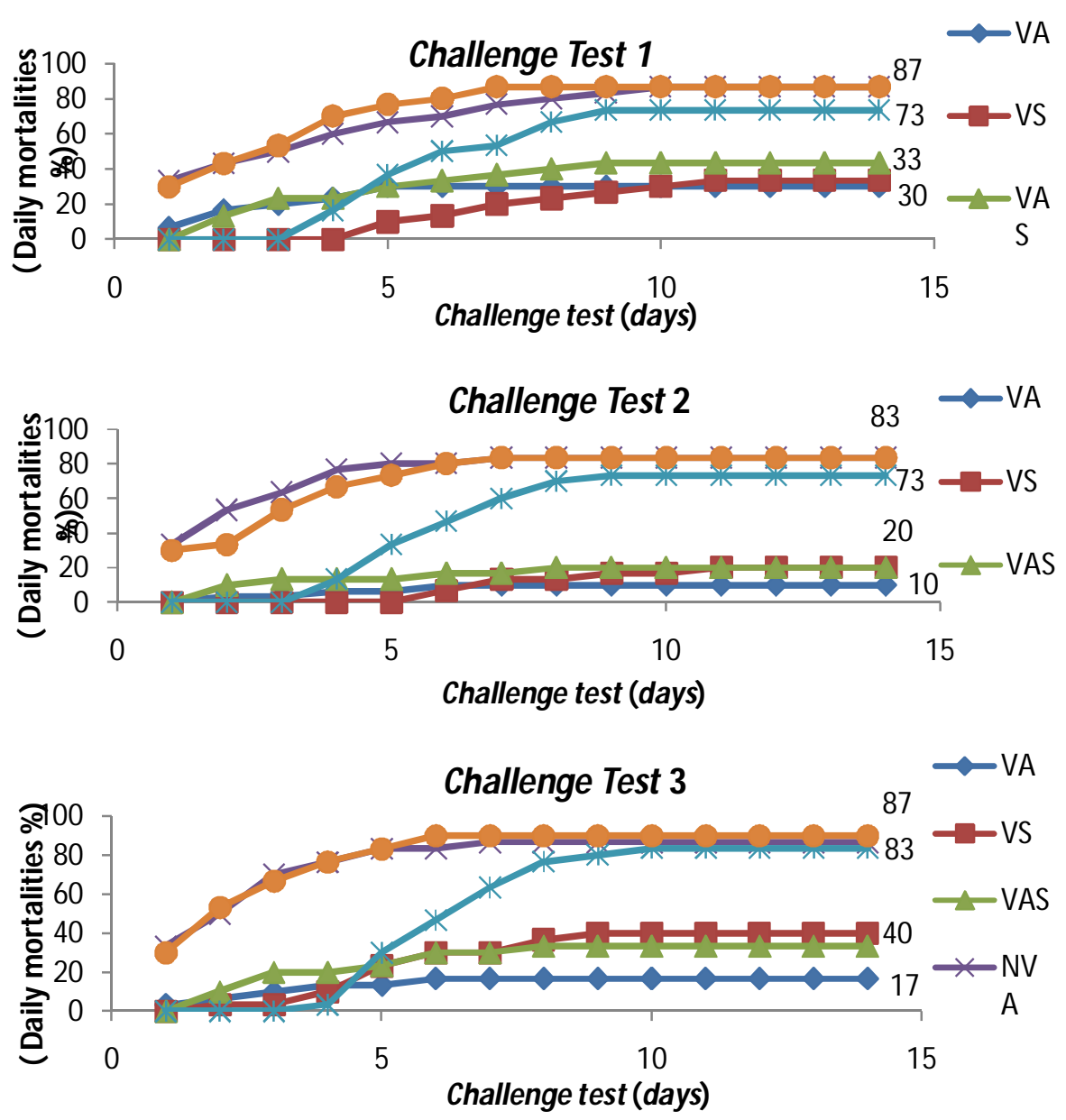

Figure 2.The mortality patterns of tilapia vaccinated with the cocktail vaccine after challenged by singleinfections of $A$. hydrophila and $S$. agalactiae, and co-infection of both bacteria on the challenge test period 1,2 and 3 . $V=$ vaccinated group, $N V=n o n-$ vaccinated group, $\mathrm{A}=A$. hydrophila, $\mathrm{S}=\mathrm{S}$. agalactiae, $\mathrm{AS}=\mathrm{Co}$-infection of $A$. hydrophila and $S$. agalactiae 
Infection patterns of those two bacteria were different, the single infection of $A$. hydrophila, and co-infection caused acute infections while $S$. agalactiae caused sub-acute infection. The mortality rate on each challenge test group was different. The observations of mortality patterns of tilapia challenged on day 22 , 50 , and 78 after vaccination, were conducted for 14 days. On all challenge test periods, the mortalities of the control fish had occurred since 24 hours after the challenge test with the single infection of $A$. hydrophila and co-infection. The mortality reached about $30 \%$ and continued to increase until day 9 with an average mortality rate of $87 \%$, and that occurred on all challenge test periods. On the vaccinated group, the mortality of the fish occurred starting from day 2 with a range about $13 \%$ for each challenge test group, and continued to occur until day 7 . Mortality rates of the vaccinated fish varied, the highest mortalities caused by the single infection of $A$. hydrophila and co-infection occurred on day 22 of the challenge test (30 and $43 \%$ ), followed by day 78 of the challenge test (17 and $40 \%$ ). The lowest mortalities occurred on day 50 with mortality rates of 10 and $20 \%$, respectively.

The mortality of the fish on the challenge test group with the single infection of $S$. agalactiae began to occur on day 4 both on the vaccinated and the control groups on all challenge test periods, except on the challenge test day 50 , the mortality of the vaccinated group began to occur on day 6 . The mortality on the vaccinated group was lower than that on the control group for each challenge test period $(P<0.05)$. The lowest mortality rate of the fish in the challenge test group with the single infection of $S$. agalactiae occurred on the challenge test on day $50(20 \%)$, followed by day 22 (33\%), and the highest on day 78 with a mortality rate of $40 \%$.

Kinetics of the fish antibodies against $A$. hydrophila have been reported by several researchers. Results of this study were in line with the study conducted by Bastardo et al. (2012) who obtained that the basal antibody concentration of rainbow trout vaccinated with bivalent vaccine against $A$. hydrophila was higher than that on Lactococcus garviae with $O D$ values of 0.101 and 0.028 , respectively. Similarly, results of the study by Dehghani et al. (2012) obtained the basal antibody concentration of rainbow trout against $A$. hydrophila at a value of 0.15 . As reported by previous studies, in this study, it could be known that the basal antibody level in tilapia against $A$. hydrophila was 0.104 . A high concentration of the fish antibody against $A$. hydrophila in this study was suspected caused by the fish had been exposed to antigens before vaccination treatments. Ismail et al. (2010) also stated that tilapia that had experienced physical contact naturally with $A$. hydrophila had antibody titer value at $\log 2$.

Results of the study by Vinay et al. (2013) stated that the OD value of rohu Labeo rohita in the control group against $A$. hydrophila ranged $0.05-0.07$, while the antibody titer OD of the fish exposed to free cells of the bacteria ranged 0.10 0.13 and the antibody titer OD of the fish vaccinated with biofilm ranged $0.40-0.67$. Those are very natural, because naturally, $A$. hydrophila is the normal microflora of the fish, this species is also widely distributed in almost all waters in the world and is able to adapt on aquatic environments with wide ranges of humidity, turbidity, $\mathrm{pH}$, salinity, and temperature (Swann and White, 1991). Therefore, the fish body will respond responsively against $A$. hydrophila, so antibody concentrations of the experimental fish serum detected will be higher. Vaccination aims to induce the long-term immunity by stimulating the component of the specific immune response that is an antibody. The antibody formation was affected by several factors, such as temperature, vaccine dose, vaccine administration method, age, the fish weight and antigen properties (Ellis, 1988).

There are contra indications in antibody kinetics of tilapia against $S$. agalactiae with some similar studies. Results of the study conducted by Pasnik et al. (2005) showed that tilapia vaccinated through injection with inactivated $S$. agalactiae vaccine had the maximal antibody concentration on day 90 post-vaccination with an OD value of 0.192 . On the other hand, the study by Sukenda et al. (2015) explained that the antibody titer value produced by vaccination through injections of $S$. agalactiae ECP, whole cells and their combination in tilapia continued to decline after 28 days post-vaccination. In this study, the maximum antibody was detected on day 56 post-vaccination by immersion with an OD value of 0.188 .

Several factors suspected to become the causes of differences in results of studies conducted were the fish size and the working seedconcentration used as the vaccine material. Pasnik et al. (2005) used tilapia with an average weight of $45.5 \mathrm{~g}$ while the experimental fish used in the study by Sukenda et al. (2015) were smaller with a weight range of $20-25 \mathrm{~g}$. The fish size very affects the protection level of a vaccine against the target pathogen. Johnson et al. 
(1982) reported that salmon with a weight of $4 \mathrm{~g}$ vaccinated with Vibrio anguillarum and Yersinia ruckeri through immersion gave a longer protection than those on 1 and $2 \mathrm{~g}$. Another factor is the working seedconcentration of the used $S$. agalactiae vaccine. The working seed concentration of $S$. agalactiae vaccine used by Sukenda et al. (2015) followed results of the study conducted by Pasnik et al. (2005) that was $10^{9} \mathrm{cfu}$. $\mathrm{mL}^{-1}$, while isolates used in those studies were different. That difference in isolate was suspected of giving different protection levels when the fish were exposed by the target pathogen. It should be known in the vaccine manufacturer that the optimum concentration has to be known first. Vaccination aims to induce the long-term immunity by stimulating the component of the specific immune response that is the antibody. The antibody formation was affected by several factors, such as temperature, vaccine dose, vaccine administration method, age, the fish weight and antigen properties (Ellis, 1988).

Specific antibody kinetics of tilapias vaccinated against $A$. hydrophila and $S$. agalactiae obtained during the rearing period correlated with the protection after conducted the challenge test with homolog antigens. On the early immunity induction period, antibodies produced were not so much so when there was an antigen exposure, the fish were not maximal in protecting themselves against an infection. This indicated by higher mortality percentages on the first challenge test period compared to the next periods. The maximum protection occurred on the second phase, indicated by the lowest mortality numbers among other two groups. On the third phase of the challenge test, although the number of antibodies had begun to decrease, but the fish were still able to protect themselves against coinfection of $A$. hydrophila and $S$. agalactiae. It made the protection value after conducted coinfection becoming the highest from those challenged on day 50 . These results were in line with several studies that were ever conducted (Pasnik et al., 2005; lbrahem et al., 2008; AbdelHadi et al., 2009; Prasad and Areechon, 2010).

There are several factors that determine vaccination outcomes, including antigen source, production method, inactivation method, concentration, dose, application method, and the addition of adjuvant (Brown, 1978; Johnson et al., 1982; Ellis, 1989; Thuvander et al., 1994; PrettoGiordano et al., 2010). Ostland et al. (2008) studied that the antibody production against an antigen usually took several weeks although this depended on fish species and water temperature, where $T$ helper cells and $B$ cells that recognize foreign molecules of an antigen, will induce specific immune responses of a known antigen.

Thuvander et al. (1987) explained that vaccination on rainbow trout juvenile with Vibrio anguillarum bacterin triggered a high protective immunity level and it lasted long at least for 46 weeks. Pasnik et al. (2005) analyzed that tilapia vaccinated with ECP and whole cells of $S$. agalactiae through injection until day 90 still provided a protection up to $62 \%$. Plumb (1984) explained that a higher antibody titer could not always be interpreted to provide a high protection or immunity level as well. But a thing that could be studied from results of this study was vaccination on tilapia through immersion with a combined cocktail vaccine of $A$. hydrophila and $S$. agalactiae could induce the specific immune response against homolog antigens. Kinetics of the antibody production resulted from that cocktail vaccine reached the peaks at different times. This indicated that specific immune response resulted by the body would be different on different antigens.

Results of this study demonstrated that the protection level of tilapia on the infection of $A$. hydrophila was higher compared to those on $S$. agalactiae and co-infection after the challenge test using $\mathrm{LD}_{50}$ dose. This was suspected to relate to differences on characteristics, antigenicities, and virulence levels of those antigens. A. hydrophila is Gram negative bacterium, while $S$. agalactiae belongs on Gram positive bacterium. According to Williams (2003) virulence components of Gram positive bacteria are their exotoxins (ECP and other toxins), on the contrary with Gram negative bacteria, LPS (endotoxin) is more virulent. Moreover, PrettoGiordano et al (2010) stated that factors that could cause an immunogenicity of an antigen were complex chemical compounds of an antigen and epitope or antigenic determinant. $A$. hydrophila has multivalent determinants that are outer membrane protein $\mathrm{F}(\mathrm{OmpF}) 47 \mathrm{kDa}$, thermostable hemolysis protein $50 \mathrm{kDa}$ derived from ECP, lipopolysaccharide 31-38 kDa and Slayers or Paracrystalline surface protein $52 \mathrm{kDa}$. $S$. agalactiae only has cell surface protein that provides a protective immunity. Sugiani (2012) analyzed that $A$. hydrophila at a high dose (LD 100$)$ is more deadly on tilapia compared to $S$. agalactiae. For $S$. agalactiae applies the opposite, in a low dose $\left(L D_{50}\right)$, this species is more virulent compared to $A$. hydrophila on tilapia.

Bacteria as antigens used as sources of vaccine materials in this study were composed of 
protein compounds that had different levels and sizes on each compiler structure. The protein profiles of bacteria can be used as a reference in determining the immunogenic potential of a vaccine, because each protein has different immunogenic capabilities. In addition, protein profiles can be used as identification characters to see strains of bacteria, as conducted by Korkoca and Boynukara (2003).

Based on results of the study by Sugiani (2012) there were differences in protein bands resulted by $A$. hydrophila and $S$. agalactiae whole cell vaccine inactivated by formaldehyde. The characterization of $A$. hydrophila protein using SDS-PAGE resulted 17 protein bands, including $143.72 ; 119.57$; $110.51 ; 94.39 ; 72.57$; 58.81; 51.57; 34.77; 31.30; 28.18; 25.36; 22.83; 19.50; $15.80 ; 15.00 ; 13.50$; and $11.53 \mathrm{kDa}$. For the same strain, Purwaningsih (2013) analyzed $A$. hydrophila monovalent vaccine demonstrating protein bands sizing 103.48, 83.76, 72.76, 64.70, 53.62, 51.16, 45.50, 35.98, 27.79, 24.14, 22.50, $16.58,14.74,12.50$ and $7.29 \mathrm{kDa}$. On the other hand, protein bands of $S$. agalactiae in the study by Sugiani (2012) were 10 bands that were 111.86; 83.42; 79.09; 58.98; 54.45; 34.61; 23.20; 18.74; 17.77 ; and $15.97 \mathrm{kDa}$.

Stuart (1999) analyzed that an immunogenic antigen molecule had a size more than $60 \mathrm{kDa}$. According to Perez et al. (2002) stated that acetylcholinesterase protoxin that was the protein molecule sizing $45 \mathrm{kDa}$ owned by $A$. hydrophila could induce the immune response of trout. Poobalane (2007) analyzed that a protein of A. hydrophila with a size of $50 \mathrm{kDa}$ was a molecule that was very immunogenic. Amrullah et al. (2014) analyzed that ECP protein toxin of $S$. agalactiae sizing $89 \mathrm{kDa}$ could increase specific and non-specific immune responses on tilapia.

A long protective immunity generated by cocktail vaccination in tilapia indicated that it might not need re-vaccination (booster) for the rearing of the fish with a rearing period that was similar to the rearing period in this study that was about four months. However, if vaccination is conducted at nursery until grow-out period with a rearing duration up to eight months or for the rearing of the broodstock candidate with a rearing period for 6-14 months, so before the primary antibody heading to the decline phase, booster should be performed, so the fish is expected to be able to increase immune responses through the formation of the secondary antibody, so those antibodies can provide a protection when there is a similar antigen exposure during the rearing period.

\section{Conclusion}

In conclusion, the basal antibody level in the fish before vaccination against $A$. hydrophila was higher than that against $S$. agalactiae. A. hydrophila and $S$. agalactiae bacterins cocktail vaccination could induce and increase the production of specific antibodies in tilapia, and the maximum antibody responses were reached within 70 days against $A$. hydrophila and 56 days against $S$. agalactiae. The lowest mortality rates were obtained on day 50 of the challenge test period in the vaccinated tilapias against $A$. hydrophila, S. agalactiae, and co-infection.

\section{Acknowledgment}

Thanks to Center for Research and Development of Freshwater Culture for test laboratory facilities so this research could be completed properly.

\section{References}

Abdel-Hadi, Y.M., Shamsudin, M.N., Yussof, K., Zakaria, S. 2009. Indoor study on the immunization of red tilapia: Oreohromis niloticus $x \quad 0$. mossambicus against aeromonad and pseudomonad septicemias. Journal of Fisheries International4(3): 45-51.

Alavandi, S.V., Ananthan, S. 2003. Biochemical characteristics serogroups, and virulence factors of Aeromonas species isolated from cases of diarrhoea and domestic water samples in Chennai, Indian. Journal of Medical Microbiology21 (4): 233-238.

Ali, H.M. 1997. The effect of adjuvant on immunization of the Nile tilapia, Oreochromis niloticus with Aeromonas hydrophila bacterin. Journal of King Saud University 9(1): 35-41.

Amrullah, Sukenda, Harris, E., Alimuddin, Lusiastuti, A.M. 2014. Immunogenicity of the $89 \mathrm{kDa}$ toxin protein from extracellular products of streptococcus in Oreochromis niloticus. Journal of Fisheries and Aquatic Science 9(4): 176-186.

Angka, S.L., Lamb, T.J., Sin, Y.M. 1995. Some virulence characteristics of Aeromonas hydrophila in walking catfish (Clarias gariepinus). Aquaculture 130: 103-112. 
Bastardo, A., Ravelo, C., Castro, N., Calheiros, J., Romalde, J.L. 2012. Effectiveness of bivalent vaccines against Aeromonas hydrophila and Lactococcus garvieae infections in rainbow trout Oncorhynchus mykiss (Walbaum). Fish and Shellfish Immunology 32: 756-761.

Brown, A.I. 1978. Immunity and Practical Vaccine Development. Marine Fisheries Review40(3): 2-5.

Dehghani, S., Akhlaghi, M., Dehghani, M. 2012. Efficacy of formalin-killed, heat-killed and lipopolysaccharide vaccines against motile aeromonads infection in rainbow trout (Oncorhynchus mykiss). Global Veterinaria 9(4): 409-415.

Ellis AE. 1988. Current aspects of fish vaccination.Diseases of Aquatic Organisms 4(2): 159-164

Ellis AE. 1989. General Principles Of Fish Vaccination. In: Ellis A-E (ed) Fish Vaccination. London: Academic Press.

Hardi, E.H., Sukenda, Harris, E., Lusiastuti, A.M.2010. Efikasi sel utuh dan produk ekstraselular bakteri Streptococcus agalactiae tipe $\beta$-haemolitik dan non haemolitik sebagai vaksin untuk pencegahan streptococcosis pada ikan tilapia (Oreochromis niloticus). Simposium Bioteknologi Akuakultur III, Oktober 2010. Bogor.

lbrahem, M.D., Arab, R.M.H., Mostafa, M.M., Rezk, M.A. 2008. Evaluation of different vaccination strategies for control of mas in Nile tilapia $O$. Niloticus In Egypt. $8^{\text {th }}$ International Symposium on Tilapia in Aquaculture 2008. hlm $1157-1175$.

Ismail, N.D.A., Atta, N.S., Aziz, A.E. 2010. Oral vaccination of Nile tilapia (Oreochromis niloticus). European Association of Fish Pathologists 19(1): 1-3.

Iwama, G., Nakanishi, T. 1996. The Fish Immune System, Organism, Pathogen and Environment. USA: Academic Press.

Johnson, K.A,, Flynn, J.K., Amend, D.F. 1982. Duration of immunity in salmonids vaccinated by direct immersion with Yersinia ruckeri and Vibrio anguillarum bacterins. Journal of Fish Diseases 5: 207213.
Korkoca, H., Boynukara, B. 2003. The Characterization of protein profiles of the Aeromonas hydrophila and A. caviae strains isolated from gull and rainbow trout feces by SDS-PAGE. Turkish Journal of Veterinary and Animal Sciences27: 1.173-1.177.

Ostland, V., Alcom, S., LaPatra, S., Harbell, S., Friedman, C., Winton, J. 2008. Measurement of rainbow trout and hybrid striped bass antibody using an enzymelinked immunosorbent assay (ELISA). Washington: WRAC Publications.

Pasnik, D.J., Evans, J.J., Klesius, P.H. 2005. Duration of protective antibodies and correlation with survival in Nile tilapia Oreochromis niloticus following Streptococcus agalactiae. Diseases of Aquatic Organisms 66: 129-134.

Pasnik, D.J., Evans, J.J., Klesius, P.H. 2006. Passive immunization of Nile tilapia (Oreochromis niloticus) provides significant protection against Streptococcus agalactiae. Fish and Shellfish Immunology 21(4): 365-371.

Perez, M.J., Rodriguez, L.A., Fernandez-Briera, A., Nieto, T.P. 2002. A 45-kDa acetylcholinesterase protoxin of Aeromonas hydrophila: purification and immunogenicity in fish. FEMS Microbiology Letters 211: 23-27.

Plumb, J.A., 1984. Immunization of warm water fish against five important pathogens [Aeromonas hydrophila, Edwardsiella ictaluri, Edwardsiella tarda, Ichthyophtirius multifiliis; catfish]. In Symposium sur la Vaccination des Poissons, Paris (France), 20-22 Feb 1984.OIE.

Poobalane, S. 2007. Aeromonas hydrophila vaccine development using immuno proteomics [Thesis] Institute of Aquaculture, University of Stirling.

Prasad, S., Areechon, N. 2010. Efficacy of formalin-killed Aeromonas hydrophila and Streptococcus sp. vaccine in red tilapia. Our Nature 8(1): 231-240.

Pretto-Giordano, L.G., Muller, E.E., Klesius, P., da Silva, V.G. 2010. Efficacy of an experimentally inactivated Streptococcus agalactiae vaccine in Nile tilapia 
(Oreochromis niloticus) reared in Brazil. Aquaculture Research 41: 1.539-1.544.

Purwaningsih, U. 2013. Vaksin koktail sel utuh untuk pencegahan penyakit mycobacteriosis dan motile aeromonas septicemia pada ikan gurame (Osphronemus gouramy). [Tesis]. Bogor: Sekolah Pascasarjana. Institut Pertanian Bogor.

Romalde, J.L., Magarinos, B., Toranzo, A.E. 1999. Prevention of streptococcosis in turbot by ntraperitoneal vaccination: a review. Journal of Applied Ichthyology 15(6): 153-158.

Sommerset, I., Krossoy, B., Biering, E., Frost, P. 2005. Vaccines for fish in aquaculture. Vaccines4(1): 89-101.

Stuart, M. 1999. Immunology Spring. Department of Mycrobiology/lmmunology. Kirkville College of Osteopathic Medicine.

Sugiani, D., Komarudin, O. 2011. Uji efektifitas sediaan produk vaksin HydroVac terhadap pengulangan aplikasi rendaman. Prosiding Seminar Nasional Ikan VI \& Kongres Masyarakat Ikhtiologi Indonesia III: 151159.

Sugiani, D. 2012. Vaksin bivalen untuk pencegahan penyakit motile aeromonas septicemia (MAS) dan streptococcosis pada ikan nila (Oreochromis niloticus). [Disertasi]. Bogor: Sekolah Pasca sarjana Institut Pertanian Bogor.

Sugiani, D., Sukenda, Harris, E., Lusiastuti, A.M.2012. Responss imun ikan tilapia, Oreochromis niloticus, terhadap vaksin bivalen sel utuh dan ekstra selular antigen Aeromonas hydrophila dan Streptococcus agalactiae. Prosiding Forum Inovasi teknologi Akuakultur 2012 hlm 755-763.

Sugiani, D., Lusiastuti, A.M., Wiratama, E. 2014. Pengembangan metode indirect enzymelinked immunosorbent assay (ELISA) untuk mengukur respons imun humoral ikan nila, Oreochromis niloticus terhadap antigen Streptococcus agalactiae. Prosiding Forum Inovasi Teknologi Akuakultur 2014, Bandung 6-8 Mei 2014. HIm: 1.069-1.074.

Sukenda, Rusli, Nuryati, S., Hidayatullah, D. 2015. Durasi proteksi vaksin Streptococcus agalactiae untuk pencegahan streptococcosis pada ikan nila. Jurnal Akuakultur Indonesia 14(2): 192-201.

Sumiati, T., Lusiastuti, A.M., Taukhid. 2012. Pengembangan vaksin koktail (A.hydrophila-S.agalactiae) melalui rendaman dan pakan untuk pencegahan penyakit potensial pada budidaya ikan nila. Seminar Hasil Riset BPPBAT Bogor 4-5 Desember 2012.

Swann, L., White, M.R., 1991. Diagnosis and treatment of "AeromonasHydrophila" infection of fish. Aquaculture Extension, Illinois-Indiana Sea Grant Program.

Taukhid, Purwaningsih, U. 2011. Screening of Streptococcus spp. isolates as an antigen candidate in vaccine development, and its efficacy to prevent streptococcosis on tilapia, Oreochromisniloticus. Jurnal Riset Akuakultur 6(1):103-118.

Thuvander, A., Hongslo, T., Jansson, E., Sundquist, B. 1987. Duration of protective immunity and antibody titres measured by ELISA after vaccination of rainbow trout, Salmo gairdneri Richardson, against vibriosis. Journal of Fish Diseases 10(6): 479-486.

Vinay, T.N., Patil, R., Suresh Babu, P.P., Rana, R., Shankar, K.M. Evaluation of the efficiency of Aeromonas hydrophila biofilm vaccine in Labeo rohita employing monoclonal antibody based ELISA. 2(3) 2-4.

Williams, M.L., Azadi, P., Lawrence, M.L. 2003. Comparison of cellular and extracellular products expressed by virulent and attenuated strains of Edwardsiella ictaluri. Journal of Aquatic Animal Health 15: 264273. 